\title{
Research on Measurement of China's Systemically Important Banks Based on AHP-Entropy Model
}

\author{
Hui Shou ${ }^{1,2}$ \\ School of Finance \\ ${ }^{1}$ Jiangxi University of Finance and Economics \\ Nanchang, China \\ ${ }^{2}$ School of Economics and Management \\ Beijing University of Technology \\ Beijing, China \\ +86-13970014516 \\ 13970014516@163.com
}

\begin{abstract}
This paper describes AHP and Entropy model, and discusses some related theoretical and practical issues. It has developed an AHP-Entropy model to build index system of systemically important banks. It presents that systemically important banks how to select from commercial banks in China. It classifies systemically important banks according to crossborder activity, scale, relevance, subs titutability and complexity. Analysis reveals that the score of Bank of China and ICBC is much higher than that of other banks. The two banks are systemically important banks in China. My findings also reflect that the accuracy of the AHP-entropy model empower to build indicator system. It provides scientific effective reference for manage rs of commercial banks.
\end{abstract}

Keywords—Systemically important banks; Entropy model; AHP model; AHP-Entropy model; commercial banks

\section{INTRODUCTION}

The banks' reactions to market information such as asset size, asset adequacy ratio and business indicators are quite different, reflecting the heterogeneity between commercial banks. Therefore, the heterogeneity of banks has different effects on the Risk Spillover Effect of the banking system. The Financial Services Authority (FSA) ${ }^{[1]}$ defines the systemically important financial institutions as: the failure of financial institutions, due to the size, complexity and systematic relevance of financial institutions. It can produce contagious and significant damage to financial institutions. In order to reduce the systemic risk of the banking sector, the bank for International Settlements (BIS) issued a report on the importance Bank of the global system and proposed important banking assessment methods ${ }^{[2]}$.

In April 2011, on the basis of the Basel Agreement III, ${ }^{\text {[3], [4] }}$ China Banking Regulatory Commission (CBRC) issued the guidance of the new regulatory standards for the implementation of China's banking industry, setting up a set of prudential supervision system for maintaining the long-term and steady operation of the banking system. The CBRC has put forward specific regulatory measures for improving the prudential regulatory standards, enhancing the effectiveness of systematic importance of banking supervision. The new capital regulatory requirements began in January 1, 2012, and systemically important banks reach new capital regulatory standards by the end of 2018. This paper uses AHP-Entropy model to identify China's systemically important banks.

\section{IDENTIFICATION INDEX SELECTION OF SYSTEMICALLY IMPORTANT BANKS}

According to the actual situation of China's banking industry, the four large state-owned commercial banks have a large proportion of the scale and the amount of their business, referring to the disclosure guidelines issued by China Banking Regulatory Commission in January 2014. The disclosure guidelines for the importance assessment of the global system of commercial banks have promulgated 12 indicators. These are the balance of foreign capital, the assets of the financial institutions and the financial machine Inter construction liabilities, issuance of securities and other financing instruments, payment by payment system or agent bank, managed assets, underwriting of securities, nominal capital of over-the-counter derivatives, trade and available securities, third levels of assets, cross-border debt and cross-border liabilities. From the scale, relevance, replaceable, complexity and cross-border activity of the bank, this paper construct the index system to evaluate the systematic importance Bank of China's banking industry.

1) The scale of assets. The size of bank assets is a significant factor to weigh the importance of the system. The larger scale of bank assets shows that the stronger the ability to resist risks. However, once banks fail, the harm to the banking system will be greater. Using the balance of assets in the table, this paper utilizes the balance of assets inside and outside the table as the evaluation index. The symbol TA indicates that the assets really bring the risk to the bank is out of balance assets, although the proportion of the assets is not high, but the risk exposure is great.

2) System relevance. The interrelationship between big commercial banks and small banks makes financial risks spread rapidly in the banking system, which seriously affects the banking system and the real economy. If a single bank goes bankrupt, it can rapidly spread risks through interbank 
correlation. This will increase the possibility of a financial crisis in the entire banking system. There are 3 indicators for the index of relevance. Including assets in the banking system, liabilities in the banking system and bank issuing securities balances. The interbank assets (symbols: BA) and interbank liabilities (BL) are used as the evaluation indicators. Interbank assets include the amount of money in the industry and other financial institutions and the purchase of repurchase assets on the balance sheet. Interbank liabilities include deposits and sales of repurchase assets on the balance sheet and other financial institutions.

3) Replaceable. When the system of systemically important banking has a high market share and a large market share, it means that other banks can't provide similar financial products. If banks are in a difficult position and unable to provide the financial services, they may cause insufficient liquidity in the market. The bank's failure has a great impact on the whole banking system. The smaller the degree of substitutable service provided by banks, the more important it is in the whole system. When the crisis occurs, the impact on the whole banking system will be greater. The systemic importance of banks is negatively related to the substitutability of financial services. This paper uses the balance of bank loans (symbol: LO) and bank balance (symbol: DE) as an evaluation index.

4) Complexity. The complexity of the bank includes the complexity of the bank's organizational structure, financial derivatives and business operation. The derivation of complex financial derivatives has brought uncertainty to the liquidity of the entire financial market and expanded the operational risk of banks. It includes: (1) derivative financial assets and liabilities. (2) Trading financial assets and liabilities and available for sale securities. A bank's trading account holds a large number of marketable securities. When liquidity crisis occurs, it will sell the marketable securities, which will reduce the price of the securities. The sharp fluctuation of short-term securities prices brings uncertainty risk to banks. The Risk Spillover Effect of banks spreads risks to the whole banking system. This paper selects derivative financial assets (symbol: DA) and derivative financial liabilities (symbol: DL) as evaluation indicators.

5) Cross-border activity of the bank. With the rapid growth of China's foreign-related economy, domestic and foreign financial institutions of financial and non-financial institutions are growing more and more economically. The cross-border investment and financing modes of commercial banks are diversified and complicated, including cross-border bank claims and cross-border bank liabilities. I take into account that bank risks come mainly from loans and investments. This article chooses the bank's cross-border debt (symbol: CR) as an evaluation index.

The specific evaluation indicators and weights are shown in TABLE I.

TABLE I. SYSTEMIC IMPORT ANT BANKS EVALUATION INDEX SYSTEM AND WEIGHT

\begin{tabular}{|c|c|c|c|}
\hline $\begin{array}{c}\text { Index and } \\
\text { weight }\end{array}$ & CBRC evaluation index & Evaluation indicators & weight \\
\hline $\begin{array}{c}\text { The scale of } \\
\text { assets } \\
\text { (H1) }\end{array}$ & $\begin{array}{c}\text { Adjusted balance of } \\
\text { assets inside and outside } \\
\text { the table }\end{array}$ & $\begin{array}{c}\text { Balance of assets } \\
\text { inside and } \\
\text { outside(TA) }\end{array}$ & $20 \%$ \\
\hline
\end{tabular}

\begin{tabular}{|c|c|c|c|}
\hline \multicolumn{4}{|c|}{ Cont. to TABLE I } \\
\hline $\begin{array}{l}\text { System } \\
\text { relevance } \\
(\mathrm{H} 2)\end{array}$ & $\begin{array}{c}\text { Financial inter agency } \\
\text { assets, } \\
\text { Financial inter agency } \\
\text { liabilities, } \\
\text { Issuing securities and } \\
\text { other financing tools }\end{array}$ & $\begin{array}{c}\text { Financial inter } \\
\text { agency assets(BA) } \\
\text { Financial inter } \\
\text { agency } \\
\text { liabilities(BL) }\end{array}$ & $20 \%$ \\
\hline $\begin{array}{l}\text { Replaceable } \\
\text { (H3) }\end{array}$ & $\begin{array}{l}\text { Payment by payment } \\
\text { system or agent line, } \\
\text { Assets Under Custody, } \\
\text { Underwriting of } \\
\text { negotiable securities }\end{array}$ & $\begin{array}{l}\text { Bank loan balance } \\
\text { (LO) } \\
\text { Bank balance (DE) }\end{array}$ & $20 \%$ \\
\hline $\begin{array}{l}\text { Complexity } \\
\text { (H4) }\end{array}$ & $\begin{array}{c}\text { Nominal principal of } \\
\text { over-the-counter } \\
\text { derivatives, } \\
\text { Trading and marketable } \\
\text { securities, } \\
\text { Third level assets }\end{array}$ & $\begin{array}{l}\text { Derivative financial } \\
\text { assets (DA) } \\
\text { Derivative financial } \\
\text { liabilities (DL) }\end{array}$ & $20 \%$ \\
\hline $\begin{array}{l}\text { Cross-border } \\
\text { activity } \\
\text { (H5) } \\
\end{array}$ & $\begin{array}{l}\text { Cross-border claims, } \\
\text { Cross-border liabilities }\end{array}$ & $\begin{array}{l}\text { Cross-border bank } \\
\text { claims (CR) }\end{array}$ & $20 \%$ \\
\hline
\end{tabular}

\section{MODEL BUILDING}

\section{A. AHP model}

In the mid-1970s, the analytic hierarchy process (AHP) formally proposed by the U.S. operations research T.L.Saaty. ${ }^{[5]}$ It is a combination of qualitative and quantitative, systematic, hierarchical analysis methods. There are four basic steps:

1) Build a hierarchical model, establishing standards level and index level.

2) Construct paired comparison matrix :

$$
A=\left(a_{i j}\right)_{n \times n}=\left[\begin{array}{cccc}
a_{11} & a_{12} & \cdots & a_{1 n} \\
a_{21} & a_{22} & \cdots & a_{2 n} \\
\vdots & \vdots & \cdots & \vdots \\
a_{n 1} & a_{n 2} & \cdots & a_{n n}
\end{array}\right]
$$

A is Comparison Matrix, $a_{i j}>0, a_{i j}=1 / a_{j i}, a_{i i}=1$

TABLE II. SAATY'S ASSIGNMENT BY PROPORTIONAL SCALING METHOD

\begin{tabular}{|c|l|}
\hline$a_{i j}$ & Compare the importance of indicators \\
\hline $\mathbf{1}$ & Index ai is the same importance than index aj \\
\hline $\mathbf{3}$ & Index ai is more importance than index aj \\
\hline $\mathbf{5}$ & Index ai is obvious importance than index aj \\
\hline $\mathbf{7}$ & Index ai is the intense importance than index aj \\
\hline $\mathbf{9}$ & Index ai is extreme importance than index aj \\
\hline $\mathbf{2 , 4 , 6 , 8}$ & The importance of values between the determination \\
\hline
\end{tabular}

Calculating weight vector normalized each column vector A:

$$
\tilde{w}_{i j}=a_{i j} / \sum_{n=1}^{n} a_{i j}
$$

3) Consistency test
a) Consistency index: $C I=\frac{\lambda-n}{n-1}$
b) Random consistency index RI 
TABLE III. RANDOM CONSISTENCY SCALE

\begin{tabular}{|l|l|l|l|l|l|l|l|l|}
\hline $\mathbf{n}$ & $\mathbf{3}$ & $\mathbf{4}$ & $\mathbf{5}$ & $\mathbf{6}$ & $\mathbf{7}$ & $\mathbf{8}$ & $\mathbf{9}$ & $\mathbf{1 0}$ \\
\hline $\mathbf{R I}$ & 0.58 & 0.9 & 1.12 & 1.24 & 1.32 & 1.41 & 1.45 & 1.49 \\
\hline
\end{tabular}

c) Consistency ratio: $\mathrm{CR}=\mathrm{CI} / \mathrm{RI}$, when $\mathrm{CR}<0.1$, we can accept inconsistency of A.

\section{B. Entropy model}

In information theory, the information system is a measure of the degree of ordering, and we measure the degree of disorder by system information entropy, the functions: ${ }^{6]}$

$$
H(x)=-\sum_{i=1}^{n} p\left(x_{i}\right) \ln p\left(x_{i}\right)
$$

Entropy method is a useful information entropy tool, depending on the degree of variation to calculate index value. An indicator changes greater from degree of variation, it provides the more amount of information. This means that information entropy is smaller, and the indicators occupy greater the weight, vice versa.

Entropy method steps:

In the original data matrix indicators $X=\left(x_{i j}\right)_{m \times n}, \mathrm{~m}$ is kind of evaluation of programs, $n$ is kind of evaluation index. First, the index is used to dimensionless data by extreme method:

$$
X_{i j}=\frac{D-x_{i j}}{d-x_{i j}}
$$

Where $\mathrm{D}$ is the maximum, $\mathrm{d}$ is the minimum.

(1) Calculating the proportion of the index $\mathrm{j}$ value under the first paragraph i programs:

$$
P_{i j}=x_{i j} / \sum_{i=1}^{m} x_{i j}
$$

(2) Calculating item j index entropy:

$$
e_{j}=-k \sum_{i=1}^{m} p_{i j} \ln p_{i j}
$$

(3) Calculating item j indexes coefficient of variation, and defined coefficient of variation:

$$
g_{j}=1-e_{j}
$$

\section{AHP-Entropy model}

Entropy theory is a method to calculate the degree of difference, according to the same index weights observations. The larger differences observed value to index, the greater weight put to indicators. In some important indicators have small differences observed values, and the non-importance of index observations have large differences. There is no reasonable that the weights of the importance of index is small, the weights of the non-importance of index is large. To reduce such unreasonable happens, this paper firstly use AHP methods to put weights to indicators, which ensure the greater importance index have large weights. Then use the entropy method to adjust the weights of AHP. Taking this method, not only ensure the importance of indicators get more weights, but also reduce the shortage of subjective AHP method. I combine subjective and objective method to evaluate comprehensive indicators, obtaining more reasonable and accurate index weights.

I am adjusting the weight of AHP by Entropy method:

$$
w_{j}=w g_{j} / \sum_{j=1}^{n} w g_{j}
$$

\section{RESULTS AND ANALYSIS OF SYSTEMATIC IMPORTANT BANK IDENTIFICATION AND EVALUATION}

\section{A. Empirical results}

This paper selects 16 listed banks as a sample of banks in China. These are ICBC, Bank of China, China Agricultural Bank, China Construction Bank, China traffic bank, China Merchants Bank, China Merchants Bank, China Merchants Bank, CITIC Bank, Minsheng Bank, Xingye Bank, Ping An Bank, Pufa Bank, Bank of Beijing and Bank of Ningbo. According to the index system and evaluation method designed in this paper, I use 2016 annual data to evaluate the systematic importance of 16 listed banks. The data come from the Bankscope database and the annual reports of banks.

TABLE IV. EVALUATION RESULT OF SYSTEMIC IMPORT ANT BANKS OF CHINA (END OF 2016)

\begin{tabular}{|l|l|l|l|l|l|l|}
\hline Bank & H1 & H2 & H3 & H4 & H5 & Total \\
\hline Bank1 & 0.22 & 0.13 & 0.19 & 0.17 & 0.18 & 0.89 \\
\hline Bank2 & 0.15 & 0.18 & 0.18 & 0.20 & 0.20 & 0.91 \\
\hline Bank3 & 0.15 & 0.11 & 0.15 & 0.15 & 0.14 & 0.70 \\
\hline Bank4 & 0.16 & 0.09 & 0.17 & 0.12 & 0.14 & 0.68 \\
\hline Bank5 & 0.05 & 0.08 & 0.07 & 0.09 & 0.06 & 0.35 \\
\hline Bank6 & 0.02 & 0.04 & 0.02 & 0.01 & 0.02 & 0.11 \\
\hline Bank7 & 0.04 & 0.05 & 0.05 & 0.04 & 0.03 & 0.12 \\
\hline Bank8 & 0.02 & 0.03 & 0.02 & 0.01 & 0.02 & 0.10 \\
\hline Bank9 & 0.03 & 0.04 & 0.03 & 0.02 & 0.01 & 0.13 \\
\hline Bank10 & 0.03 & 0.04 & 0.03 & 0.02 & 0.02 & 0.14 \\
\hline Bank11 & 0.03 & 0.03 & 0.02 & 0.01 & 0.02 & 0.11 \\
\hline Bank12 & 0.01 & 0.02 & 0.01 & 0.02 & 0.01 & 0.07 \\
\hline Bank13 & 0.03 & 0.05 & 0.02 & 0.01 & 0.02 & 0.13 \\
\hline Bank14 & 0.01 & 0.02 & 0.006 & 0.005 & 0.01 & 0.05 \\
\hline Bank15 & 0.003 & 0.01 & 0.002 & 0.004 & 0.005 & 0.01 \\
\hline Bank16 & 0.004 & 0.01 & 0.001 & 0.002 & 0.006 & 0.01 \\
\hline
\end{tabular}

\section{B. Result analysis}

From TABLE IV, the Bank of China, the industrial and commercial bank, the Agricultural Bank, the Construction Bank and the Bank of communications are far higher than the other banks. The results indicate that the five banks are in the importance of the Chinese banking system. Among them, the Bank of China and ICBC scored far higher than other banks. These two banks are systemically important banks in China. ICBC has larger assets than the Bank of China, while Bank of China is stronger than ICBC in cross-border banking business. 
The overall score of the joint-stock commercial bank is about 0.1. Urban commercial banks have lower scores. The score of city commercial banks is lower. From the perspective of asset size and substitution, these two types of banks belong to China's no systemically important banks.

\section{SUMMARY}

Regulatory authorities impose higher regulatory requirements on systemically important banks in order to reduce the possibility of systemic failure. This will reduce the negative external effects and impact on the banking system and the macro-economy. Banks need government guarantees to reduce government investment and maintain fair competition in the market.

The results show that: First, the commercial banks are evaluated and divided into two categories according to the scale, relevance, complexity, substitutability and cross-border activity. Second, the supervisor should strengthen macro prudential supervision to systemically importance banks, and to raise systematic additional capital requirements. Systemically important banks and no systemically important banks are the basis for differential quantitative regulation. Third, Stricter regulatory requirements have been imposed in terms of capital adequacy ratio and length of transition. The regulatory authorities can reduce the excessive risk preference motivation of systemically important banks and effectively reduce the possibility of systemic risks in banks.

\section{REFERENCES}

[1] FSA(Financial Services Authority), Report of the Financial Stability Forum on Addressing Procyclicality in the Financial System [R].2009.

[2] G20. Guidance to assess the systemic importance of financial institutions markets and instruments: initial considerations [R]. 2009.05.

[3] Basel Committee on Banking Supervision, Basel III more resilient banks and banking systems [EB/OL]: A global regulatory framework. for www.bis.org/publ, 2010-12.

[4] Basel Committee on Banking Supervision,” Global systemically important banks: Assessment methodology and the additional loss absorbency requirement" [EB/OL], www.bis.org/publ, 2011-7.

[5] Saatty, T. L: The Analytic Hierarchy Process, New York: Mc Graw-Hill Company, 1980.

[6] Mistrulli E. Assessing financial contagion in the interbank market: maximum entropy versus observed interbank lending patterns [J]. Journal of Banking and Finance, 2010(1):1-14. 